\title{
Assessment of integrating Environmental Factors into Healthcare Models for Enhancing Timely Epidemics Analysis: A Case study of Cholera in Dar es Salaam - Tanzania
}

\author{
Dr. Judith Leo ${ }^{1}$ and Dr. Janeth Marwa ${ }^{2}$ \\ ${ }^{1}$ Lecturer, School of Computation and Communication Science and Engineering \\ Nelson Mandela African Institution of Science and Technology (NM-AIST), P.O. Box 447 Arusha \\ ${ }^{2}$ Lecturer, School of Business Studies and Humanity, Nelson Mandela African Institution of Science and \\ Technology (NM-AIST), P.O. Box 447 Arusha, Tanzania
}

\begin{abstract}
The objective of this study is to assess the perspectives of users on the feasibility of using integrated environmental factors-based healthcare model to enchance timely cholera epidemics analysis in Tanzania. The study used a mixed-design approach of quantitative and qualitative methods with focus group discussion and interviewer-administered questionnaires. Participants or users included; medical and epidemiological experts, environmental experts, Information and Communication Technology (ICT) experts, and cholera patients from Ilala, Ubungo, Kigamboni, Temeke, and Kinondoni disctricts in Dar es Salaam, Tanzania. In the process, a total of 500 interviews were conducted, consisting of 200 medical experts, 50 environmental experts, 50 ICT experts, and 200 cholera patients, with an average age of 28 years old, and at 3:2 female to male ratio. Overall, our findings showed that Health and Environmental Integrated Modelled Systems (HEIMs) interventions are acceptable, feasible and capable in assisting timely analysis towards effective prediction and eradication of epidemics such as; cholera outbreaks at $79 \%$ acceptability, 90\% aid-value and 69\% awareness levels. Despite, the high acceptability level, participants also highlighted barriers of the model, such as; sustainability and operation costs, which need to be addressed. These findings confirm that the program of HEIMS is of high potential towards enhancing timely cholera analysis, clear public health significance and relevant to policy-makers, government, society, and related stakeholders at large. Therefore, the study, recommends that there is a need for all these organs to work together towards clearing all obstacles in order to achieve the intended goal of the HEIMs program.
\end{abstract}

Key Words: Healthcare Sytsems, Environmental Systems, Epidemic Analysis, Cholera.

\section{INTRODUCTION}

Globally, every year there are 1.3 million to 4.0 million cases, and 21,000 to 143,000 deaths due to cholera epidemics [1]. Cholera is an important public health problem caused by Vibrio-cholerae bacteria. The bacteria live in waters, and people contact the bacteria after drinking liquids or eat foods contaminated with the bacteria [2]. Cholera is very rare in the industrialized nations such as; United States, however, it is still extremely virulent in areas with inadequate water supply, hygiene, sanitation, and food safety [3] [4]. It has been reported by World Health data that cholera cases increase worldwide especially in the developing countries and tend to spread to other countries including developed countries [5]. The disease continues to be notorious and a threat to human society, due to the extraordinary scale of death and damage it brought over the history especially in the SubSaharan Africa (SSA) [6].

In SSA, the mortality ratio of cholera outbreaks is higher compared to other parts of Africa. In addition, cross border and recurrent cholera outbreaks in SSA such as; the Eastern and Southern Africa sub-regions, namely Tanzania-Kenya, Uganda-Democratic Republic of Congo, and Mozambique-Malawi, contribute to high annual reported cholera cases and death [7]. Among the countries in SSA such as Tanzania, cholera has been notorious throughout the the history and continue to be substantial health burden due to lack of proper infrastructure and mechanisms. 


\subsection{Historical Background of Cholera Disease in Tanzania}

The fourth world cholera pandemic began in 1863 and ended in 1875. This pandemic spread throughout the Middle East and was carried to Russia, Europe, North America and for the first time reached North Africa where it speaded to SSA, killing 70,000 in Tanzania in 1869. Historically, it was during this time up to date, Tanzania started to experience cholera epidemic disease [8]. In Tanzania, the first major cholera outbreak occurred in 1992 causing 18,526 cases and 2,173 deaths. Again, in 1997 another outbreak occurred in Dar es Salaam region causing 40,249 cases, 2,231 death and it had massive spread to the other seven regions including Morogoro and Tanga [9]. Several initiatives with the assistance of the Tanzanian Government, together with World Health Organization (WHO), United Nations International Children's Emmergency Fund (UNICEF), and others, have been done to control and prevent cholera epidemics through health education and trainings [10]. Despite the advances made in understanding the disease and its treatment, cholera epidemics remain to be prevalent and recurrent in most parts of Tanzania such as; Dar es Salaam, Morogoro, Tanga, Mtwara, Arusha, Singida and Unguja to mention a few [11]. Recently, in January 2015 through January 2018, 33,421 cases, including 542 deaths have been reported in Tanzania as shown in Figure 1 [5]. According to WHO [12], the cholera outbreaks have been strongly linked to the global changes in the environmental factors such as; fluctuation of weather variables such as; tempeature, rainfall, humidity and wind, geographical location, water bodies, and other environmental settings [13]. Due to these fluctuations, ICT based initiatives or mechanisms such as; Health and Environmental Management Information Systems (HEMISs) were introduced in order to understand the dynamics of environmental factors towards effective analysis, prevention and eradication of cholera epidemics in Tanzania [14].

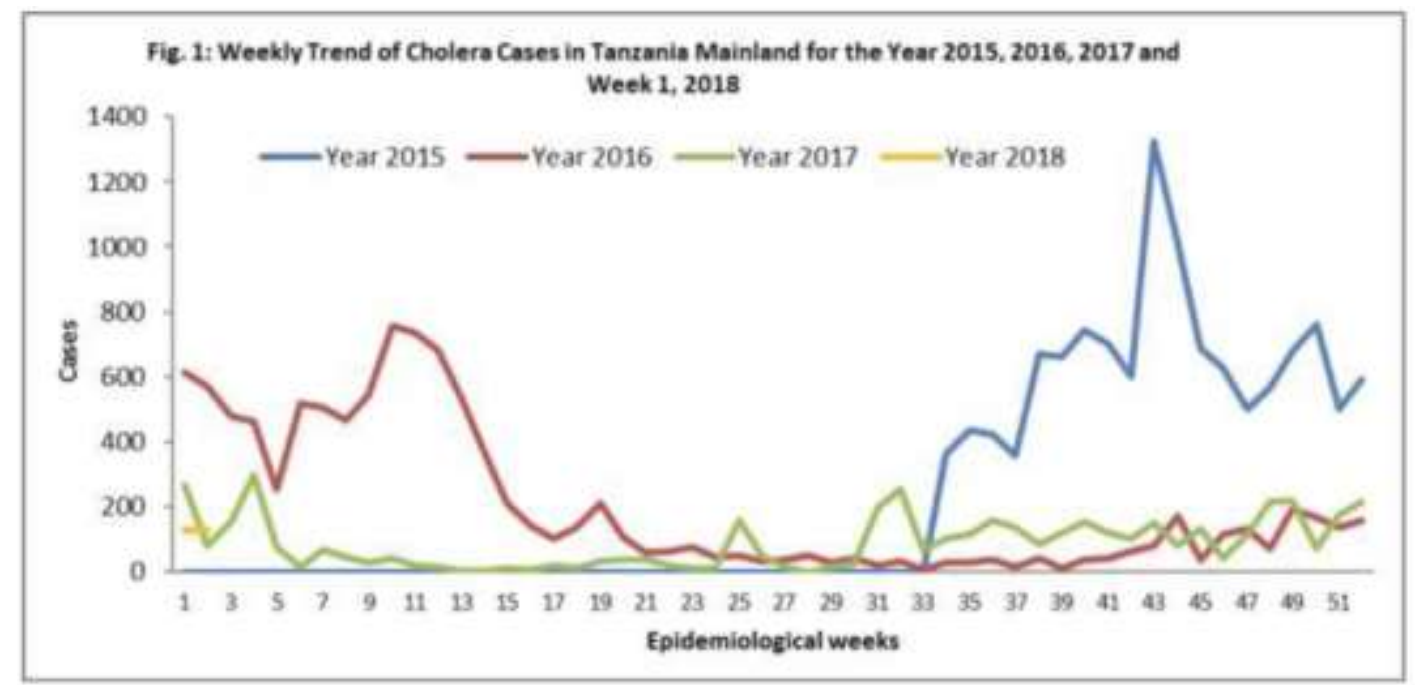

Figure1.1: Ongoing Cholera Epidemic - Tanzania, 2015-2016 by R. Narra MD et al. [9]

\subsection{Description of HEMIS initiatives in Tanzania.}

With continuous and increasing rates of morbidity associated with cholera, typhoid, dengue fever, and other waterborne diseases, especially in SSA, the use of ICTs is inevitable [15]. The rapid development of ICTs in resource limited settings such as; less staff and specialized health professionals in Tanzania proved to provide access to high quality and timely health-care services. In general, ICT has played an essential role in bridging the timely information, access, analysis, storage, prediction gap that have surfaced in the health sectors in developing countrites [16].

Nowadays, patients become more involved in their own care, and this have become more significant in managing chronic diseases such as; cholera epidemics [17]. With the help of health and environmental models such as; Epidemic Predictive Models (EPM) [18] and Health and Environmental Management Information Systems (HEMISs) patients, epidemiologists, medical and environmental experts have been able to work together towards predicting, analysing, treating and eradication diseases at large scale especially in the developed countries [19]. In brief, the HEIMSs as shown in Figure 2 enables patients to register and check for other hospital requirements via mobile phone; both basic and smart, then data is collected and sent to the Health Management Information System (HMIS) database. Then communication subsystem integrates data from HMIS and Environmental Management Information System (EMIS), and sends them into the HEMIS. At this stage, the data is ready to be sent to the registrar for further medical activities. Then the whole collected data and laboratory results of the patients are sent to the epidemiological analysts. Overall, the model allows the use of ICT applications such as; mobile application to timely send environmental and health-care data from the patient to the medical experts, GIS to collect patient geographical location, Satellite and sensor technologie to collect weather variables. Of late, the use of ICT has been remarkable deployed in Tanzania health-care 
domains [11], and therefore there is a need to assess these strategies and initiatives in order to understand their dynamics. Therefore, this study, assess the impact on the integration of environmental factors into health-care models in Dar es Salaam's health-care settings, in order to understand the impacts towards its acceptability, value-aid addition, awareness, barriers and enablers for using the technology in the collection, monitoring, analysis, prediction, eradication and overall management of cholera epidemics. The rest of this paper includes; section 2 which presents methods, section 3 which presents the results, and lastly section 4 which concludes with a brief discussion.

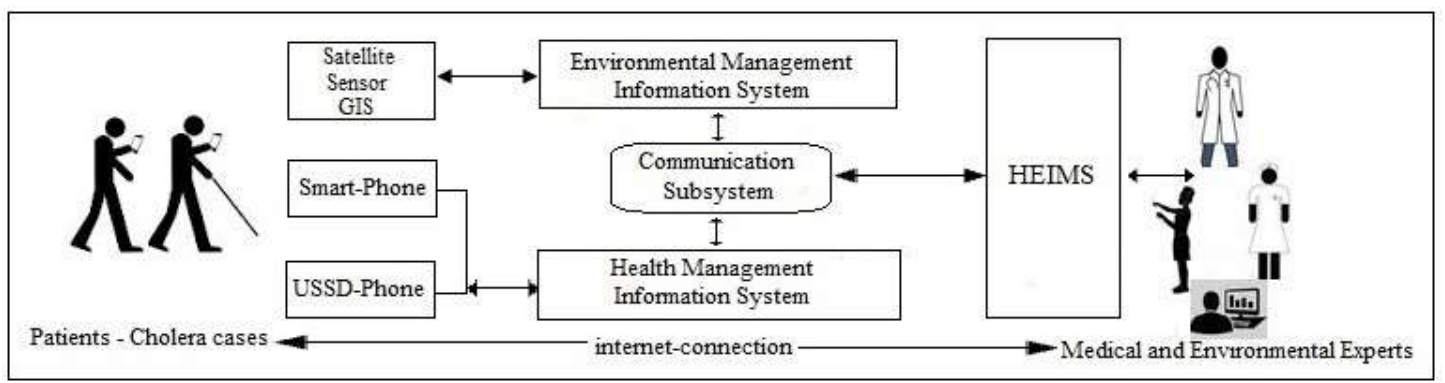

Figure 1.2: Conceptual Diagram of the HEIMS

\section{METHODS}

This study used a mixed design approach qualitative amd quantitative methods, with focus group discussions and intervieweradministered questionnaires.

\subsection{Study Area}

The study was conducted in Dar es Salaam region. Dar es Salaam is located on the east coast of Tanzania, lies between latitudes 6.45-degrees South and 7.25-degree South and longitude 39-degree E and 39.55-degree E. The region is border by Indian Ocean to the east, and the Coast (Pwani) region on the other sideas as shown in Figure 3. The region has five districts namely, Kinondoni, Ilala, Temeke, Kigamboni and Ubungo. Climatic condition in Dar es Salaam is humid and hot through the year with an average daily temperature range of 26-35 degrees C, and rainfall ranging between 800mm and 1300mm [20]. Dar es Salaam is one of the fastest growing cities in SSA, with a population of about 5,702,400 by 2018. By 2015, it was estimated that 70 percent of Dar es Salaam's population live in poor, unplanned settlements, characterized by lack of basic infrastructure such as; poorly constructed water sewage systems, bridges, and ponds, which make the region vulnerable to frequent and recurrent cholera epidemics [21].

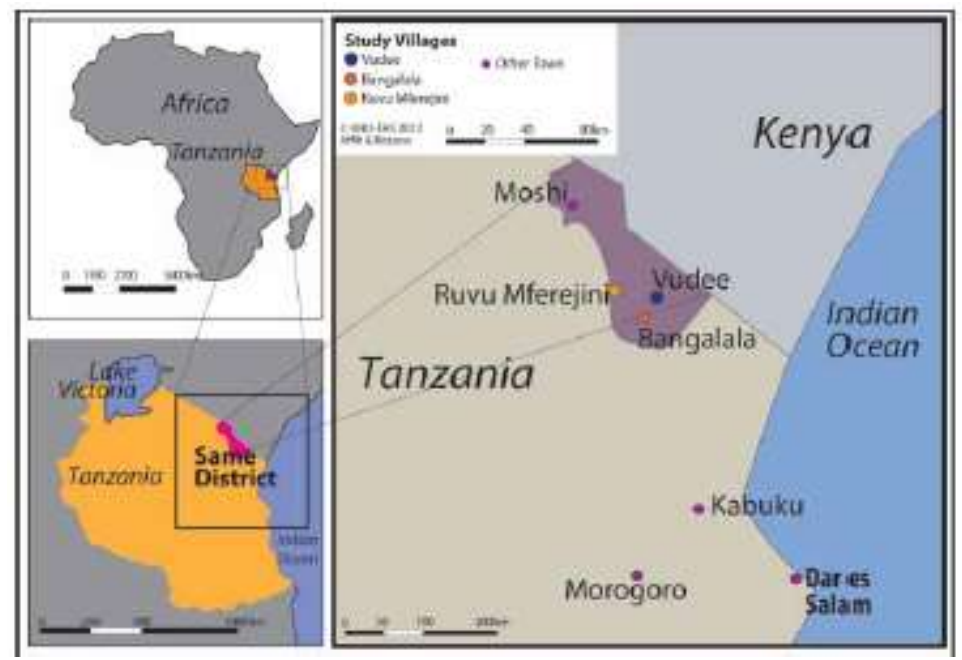

Figure 1.3: Dar es Salaam Region in Tanzania by T. Afifi et al. [22]

\subsection{Study Participants and Sampling}

The targed population with an average age 28 years old, ranging from 15 to 65 years old, includes medical experts, environmental experts, ICT experts, and patients who visited hospital to get cholera diagnosis. A simple random sampling method was used to select participants within each cluster in order to allow every member in the cluster an equal chance of being selected. Total of 
500 interviews were completed, comprising of 100 medical doctors, 30 nurses, 20 pharmacists, 50 epidemiologists, 50 environmental experts, 50 ICT experts, and 200 patients.

Table 1.1: Profile and characteristics of the participants

\begin{tabular}{|c|c|c|c|}
\hline $\begin{array}{l}\text { Characteristics of } \\
\text { participants }\end{array}$ & $\begin{array}{c}\text { Total } \\
\text { sample } \\
(\mathbf{N}=\mathbf{5 0 0})\end{array}$ & $\begin{array}{c}\text { Percentage } \\
\text { distribution }(\%)\end{array}$ & Description \\
\hline $\begin{array}{c}\text { Age in years } \\
-\quad \leq 20 \\
. \quad 21-35 \\
-\quad \geq 36\end{array}$ & $\begin{array}{l}85 \\
330 \\
85\end{array}$ & $\begin{array}{l}17 \\
66 \\
17\end{array}$ & $\begin{array}{l}\text {-The average age group for } \\
\text { the study was } 28 \text { years old. }\end{array}$ \\
\hline $\begin{array}{l}\text { Religion } \\
\text { - } \text { Christian } \\
\text { - } \text { Muslim } \\
\text { - } \text { Traditionalist } \\
\text { - None }\end{array}$ & $\begin{array}{l}260 \\
200 \\
30 \\
10\end{array}$ & $\begin{array}{l}52 \\
40 \\
6 \\
2\end{array}$ & $\begin{array}{l}\text {-None } \\
\text { participants who are not } \\
\text { affiliated with Christian, } \\
\text { Muslim and Traditionalist } \\
\text { religions. In other term, we } \\
\text { call the pagans. }\end{array}$ \\
\hline $\begin{aligned} & \text { Occupation } \\
& \text { - } \text { Trader } \\
& \text { - } \text { Artisan } \\
& \text { - } \text { Farmer } \\
& \text { - } \text { Salary worker } \\
& \text { - } \text { Medical expert } \\
& \text { - } \text { Environmental } \\
& \text { expert } \\
& \text { - } \text { ICT expert } \\
& \text { - } \text { Unemployment }\end{aligned}$ & $\begin{array}{l}50 \\
20 \\
60 \\
30 \\
200 \\
100\end{array}$ & $\begin{array}{l}10 \\
4 \\
12 \\
6 \\
40 \\
20\end{array}$ & $\begin{array}{l}\text {-Participants with Trader, } \\
\text { Artisan, Farmer, Salary } \\
\text { Worker, and Unemplyment } \\
\text { fall under Patient Cluster. }\end{array}$ \\
\hline \begin{aligned} & \multicolumn{2}{l}{ Education level } \\
& - Primary \\
& - Secondary \\
& - Certificate Level \\
& - Diploma Level \\
& - University \\
& - Non-Formal \\
& Education \end{aligned} & $\begin{array}{l}100 \\
110 \\
30 \\
40 \\
200 \\
20\end{array}$ & $\begin{array}{l}20 \\
22 \\
6 \\
8 \\
40 \\
4\end{array}$ & $\begin{array}{l}\text {-Secondary constited of } \\
\text { participants with Junior and } \\
\text { Senior High School Leves } \\
\text { at a ratio of } 3: 2 \\
\text { respectively. } \\
\text {-Non-Formal Education } \\
\text { constisted with particpants } \\
\text { who do not have any kind } \\
\text { of education. }\end{array}$ \\
\hline $\begin{aligned} & \text { Cluster level } \\
& \text { - } \text { Patient } \\
& \text { - } \text { Medical Experts } \\
& \text { - } \text { Environmental } \\
& \text { Experts } \\
& \text { - } \text { ICT Experts } \\
& \text { - } \text { Non-Clustered } \\
&\end{aligned}$ & $\begin{array}{l}200 \\
200 \\
50 \\
50 \\
0\end{array}$ & $\begin{array}{l}40 \\
40 \\
10 \\
10 \\
0\end{array}$ & $\begin{array}{l}\text {-The study was very strict } \\
\text { in selecting all participants } \\
\text { based on three ckusters. } \\
\text { Therefore, we do not have } \\
\text { participants under Non- } \\
\text { Clustered category. }\end{array}$ \\
\hline $\begin{aligned} \text { District } \\
\text { - Kinondoni } \\
\text { - } \text { Temeke } \\
\text { - Ilala } \\
\text { - Ubungo } \\
\text { - Kigamboni }\end{aligned}$ & $\begin{array}{l}100 \\
100 \\
100 \\
100 \\
100\end{array}$ & $\begin{array}{l}20 \\
20 \\
20 \\
20 \\
20\end{array}$ & $\begin{array}{l}\text {-The study considered all } \\
\text { districts in Dar es Salaam } \\
\text { regions without bias. In } \\
\text { addition, equal distribution } \\
\text { of participant ration was } \\
\text { taken into hig } \\
\text { consideration. }\end{array}$ \\
\hline $\begin{aligned} \text { Gender } & \\
\text { - } & \text { Female } \\
\text { - } & \text { Male }\end{aligned}$ & $\begin{array}{l}60 \\
40\end{array}$ & $\begin{array}{l}60 \\
40\end{array}$ & $\begin{array}{l}\text {-Majority of participants } \\
\text { were Female at Female to } \\
\text { Male ratio of } 3: 2 \text {. }\end{array}$ \\
\hline
\end{tabular}


International Journal of Advances in Scientific Research and Engineering (ijasre), Vol 7 (9), September -2021

\begin{tabular}{|c|c|c|c|}
\hline \multicolumn{4}{|l|}{ Marital status } \\
\hline - Single & 60 & 12 & - Majority of participants \\
\hline - Married & 350 & 70 & were married at a rate of \\
\hline - $\quad$ Separated & 30 & 6 & $70 \%$ \\
\hline - Cohabiting & 50 & 10 & \\
\hline - Widow & 10 & 2 & \\
\hline
\end{tabular}

The qualitative study comprised of focus group discussions and interviewer-administered questionnaires. The focus group discussion included 300 participants while, the interviewer-administered questionnaires included 200 participants mainly the medical doctors. Table 1 shows the distribution of participants based on their district and wards.

\subsection{Data Preprocessing and Analysis}

The collected quantitative data was checked for presence of error such as; missing data, typos, misspellings, completeness and accuracy. Then, the qualitative data from voice recorders and phone audio recorders were also, recorded thoroughly with a team of ten research assistants to ensure completeness and accuracy of the data. The two sets of data were integrated into one file, then repeatedly cleaned and analysed using Statistical Package for Social Science software (SPSS) [23]. Descriptive statistics including frequency and cross tabulation on all variables were run to generate results of the study.

\section{RESULTS AND DISCUSSION}

This section briefly presents the results and discussion on how participants responded to the focus group discussion and interviewer-administered questionnaires.

\subsection{Results}

The following briefly presents the on how participants responded to the focus group discussion and interviewer-administered questionnaires

Profile and characteristics of the participants: The following Table 1 present the profile and charactersitics of 500 participants used in the study with respect to their age, religion, occupation, education level, cluster level, district, gender, and maritual status.

The following Figure 1.4 presents views and feedback from participants regarding the impact of HEIMS in Dar es Salaam region in terms of;

- Acceptability Level on the impact or aid-value of HEIMS interventions: Majority of the participants are aware that, the HEIMS interventions are feasible at the rate of $79 \%$ and also, agree that these interventions will aid value at the rate of $90 \%$.

- Awareness on Cholera transmission, prevention and control: According to the WHO report, it was acknowledged that acquiring knowledge of cholera is very important strategy towards the fulfilment of the control strategies and measures [24]. However, based on our findings and used participants, it was realized that large number of participants, especially the patient cluster does not know clearly the cause and ways in which cholera can be prevented and reported for emmedite control. In addition, knowledge level on cholera prevention and control is lagging behind especially in high-risk groups with poor education. Findings of this study correspond to the findings discovered by D. Morof et al. [25], E. Burnett et al. [26], K. M. Saif-Ur-Rahman et al. [27], and V. Were et al. [28] that 79\% have good knowledge on transmission, prevention and control of cholera epidemics.

- No access to safe water and sanitation level: It was reported by B. Taylor and E. Chinamo, that only 50 percent and 34 percent of Tanzania's population of 53 million have access to improved source of safe water, and sanitation respectively [29]. Our findings indicate that many people in the rural area do not have reliable source of safe water and sanitation conditions at the rate of $65 \%$. Where as for the urban, participants have indicated that they also do not have reliable source of safe water and sanitation, however there are different strategies and projects done through Dar es Salaam Water and Sewerage Corporation (DAWASCO) and the Ministry of Water and Irrigation towards facilitating supply of safe domestic water for their daily needs. 


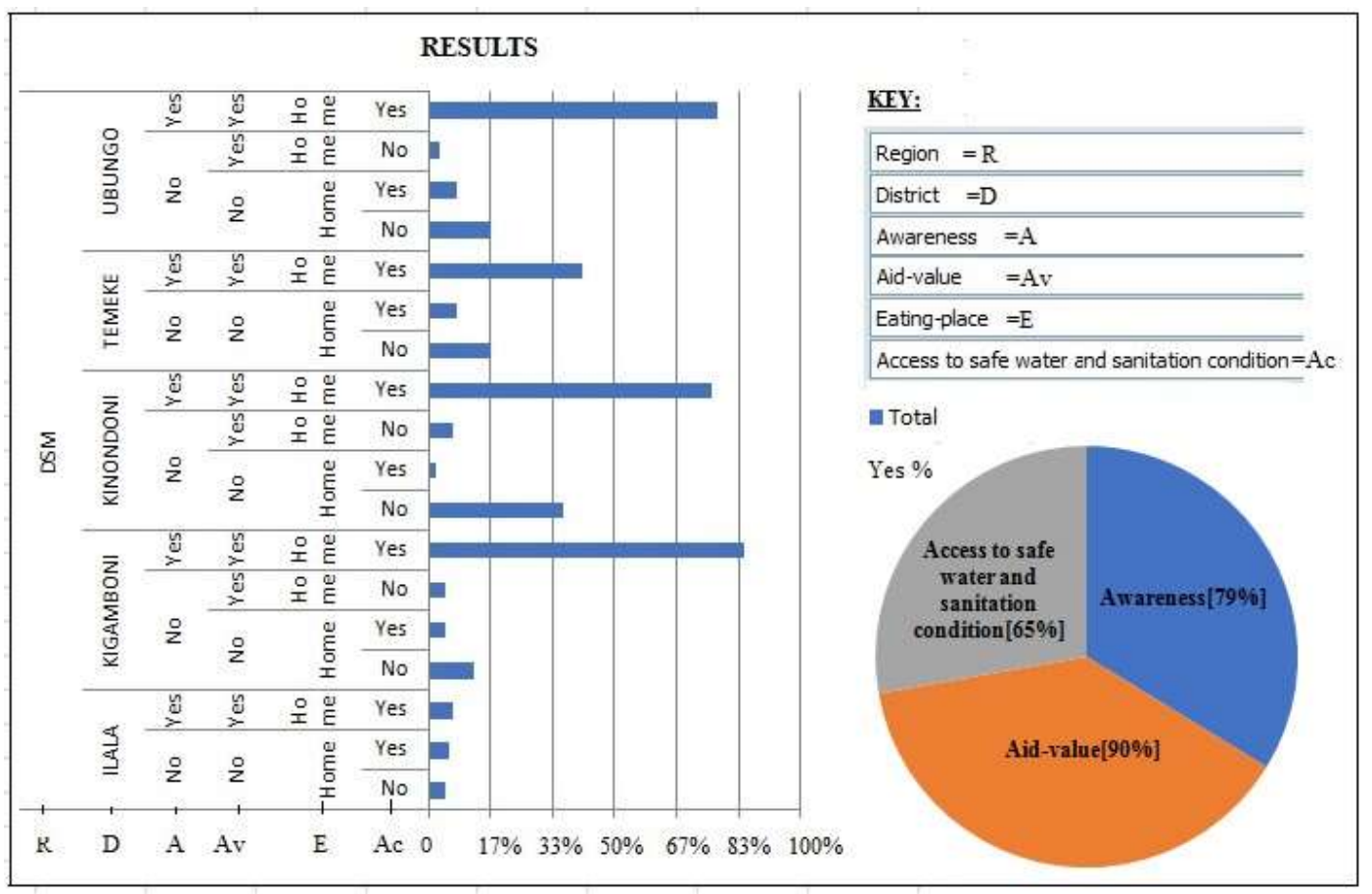

Figure 1.4: Results of participants' responds

\subsection{Discussion}

Based on our findings, the active participation of all participants; patients, and ICT, medical and environmental experts dealing with cholera variables expressed general acceptability, feasibility and positive attitude for the HEIMS interventions, especially in the timely analysis, of cholera epidemics. These findings agree with several other findings related to eHealth and mHealth interventions in SSA. However, the limited access to power supply, airtime, cost of network and ICT equipment such as; computers, mobile phone, and networking devices was highlighted in the study result. In addition, evidence indicates that pilot projects and intervention assessments in which most of the ICT initiatives are tested or assessed on a small scale often show impressive results. However, often these are not feasible and sustainable results when used in large-scale settings [29]. Participants are of the view that if these challenges are not addressed, it would be an obstacle towards provision and access of HEIM services in their settings.

Base on the resulted allegations and challenges, several trainings on how to easily access internet connection and access to reliable and cost-effective ICT equipments were done. Furthermore, the results were shared with the ministry of health and cosial welfare, companies, and various Non-Government Organisations (NGOs) responsible for eHealth intervention in Tanzania in order to assist and provide effective measures on time. As a take away, we realized that proof assessment in a large-scale implementation is necessary and therefore, there is a need for scaling up.

\section{CONCLUSION}

The effective implementation of HEIMS intervetntions is very critical in addressing timely analysis, treatment, prediction and eradication of cholera epidemics, particularly in developing countries settings such as; Tanzania. This study assessed the perspective and impact of HEIMS initiatives in Dar es Salaam region. Overall, our findings showed that the HEIMS interventions were acceptable and feasible. All participants believe that this innovation is good and if successfully scaled up and sustainability measures are taken into control, cholera epidemics with its associated symptoms such as; vomiting and diarrhoea will be effectively eradicated. As it has been observed that, our findings are of clear importance to public health, the study recommend that government, policy makers, stakeholders, program implementers and even patients to work together towards clearing all obstacles in order to achieve the intended goal of the HEIMSs program and interventions. 
International Journal of Advances in Scientific Research and Engineering (ijasre), Vol 7 (9), September -2021

DATA AVAILABILITY

The data used to support the findings of this study are available from the corresponding author upon request.

\section{CONFLICTS OF INTEREST}

The authors declare that there are no conflicts of interest regarding the publication of this paper.

\section{ETHICAL APPROVAL}

This study was reviewed and approved by the Nelson Mandela African of Science and Engineering Research Board.

\section{ACKNOWLEDGEMENT}

The author would like to thank the contribution made by the Mininsty of Health and Social Welfare, all participants, and research assistants.

\section{REFERENCE}

[1] F. Weill et al., "pandemic of cholera in Africa," Science (80-. )., vol. 789, no. November, pp. 785-789, 2017.

[2] A. Mrityunjoy, F. Kaniz, J. Fahmida, J. S. Shanzida, U. Aftab, and N. Rashed, "Prevalence of Vibrio cholerae in different food samples in the city of Dhaka, Bangladesh," Int. Food Res. J., vol. 20, no. 2, pp. 1017-1022, 2013.

[3] C. J. Miller, R. G. Feachem, and B. S. Drasar, "Cholera Epidemiology in Developed and Developing Countries: New Thoughts on Transmission, Seasonality, and Control," Lancet, vol. 325, no. 8423, pp. 261-263, 1985.

[4] S. Mandal, M. D. Mandal, and N. K. Pal, "Cholera: A great global concern,” Asian Pac. J. Trop. Med., vol. 4, no. 7, pp. 573-580, 2011.

[5] World Health Organization, “The 2015 Cholera Report,” Wkly. Epidemiol. Rec., vol. 91, no. 38, pp. 433-440, 2016.

[6] J. Lessler et al., "Mapping the burden of cholera in sub-Saharan Africa and implications for control: an analysis of data across geographical scales," Lancet, vol. 391, no. 10133, pp. 1908-1915, 2018.

[7] G. Bwire, M. Mwesawina, Y. Baluku, S. S. E. Kanyanda, and C. G. Orach, "Cross-border cholera outbreaks in SubSaharan Africa, the mystery behind the silent illness: What needs to be done?," PLoS One, vol. 11, no. 6, pp. 1-15, 2016.

[8] R. I. Glass and R. E. Black, "the Epidemiology of Cholera in India.," Lancet, vol. 213, no. 5509, p. 678, 2003.

[9] R. Narra MD et al., "Ongoing Cholera Epidemic - Tanzania, 2015-2016," MMWR. Morb. Mortal. Wkly. Rep., vol. 66, no. 6, pp. 177-178, 2017.

[10] L. de Assis Moura, "Embracing Strategies for eHealth,” Yearb. Med. Inform., vol. 10, no. 1, p. 1, 2015.

[11] N. Darcy, M. Elias, A. Swai, H. Danford, H. Rulagirwa, and S. Perera, "eHealth Strategy Development: A Case Study in Tanzania," J. Heal. Informatics Africa, vol. 2, no. 2, 2015.

[12] B. Impouma et al., "Recurring Epidemics in the Who African Region: Situation Analysis, Preparedness and Response," Africa Heal. Monit. Dis. Control, no. 15, pp. 42-47, 2007.

[13] K. Kuhn, D. Campbell-lendrum, A. Haines, and J. Cox, "Using climate to predict infectious disease epidemics," Who, p. 55, 2005.

[14] S. L. M. Trærup, R. A. Ortiz, and A. Markandya, "The Health Impacts of Climate Change : A Study of Cholera in Tanzania," Bc3, no. January, 2010.

[15] S. L. M. Trærup, R. A. Ortiz, and A. Markandya, "The costs of climate change: A study of cholera in Tanzania," Int. J. Environ. Res. Public Health, vol. 8, no. 12, pp. 4386-4405, 2011.

[16] A. A. Koepke, I. M. Longini, M. E. Halloran, J. Wakefield, and V. N. Minin, "Predictive modeling of cholera outbreaks in Bangladesh," Ann. Appl. Stat., vol. 10, no. 2, pp. 575-595, 2016.

[17] A. M. Stiggelbout et al., "Shared decision making: Really putting patients at the centre of healthcare," BMJ, vol. 344, no. 7842, pp. 1-6, 2012.

[18] R. C. Ngeleja, L. S. Luboobi, and Y. Nkansah-Gyekye, "The Effect of Seasonal Weather Variation on the Dynamics of the Plague Disease," Int. J. Math. Math. Sci., vol. 2017, pp. 1-25, 2017.

[19] M. Smith, S. Madon, E. Michael, A. Anifalaje, and M. Lazarro-Malecela, "Integrated Health Information Systems in Tanzania: Experience and Challenges,” Electron. J. Inf. Syst. Dev. Ctries., vol. 33, no. 1, pp. 1-21, 2017.

[20] G. H. Leyna et al., "Profile: The Dar Es Salaam health and demographic surveillance system (Dar es Salaam HDSS)," Int. J. Epidemiol., vol. 46, no. 3, pp. 801-808, 2017.

[21] K. Zimmerman, A. A. Mzige, P. L. Kibatala, L. M. Museru, and A. Guerrero, "Road traffic injury incidence and crash characteristics in Dar es Salaam: A population based study,” Accid. Anal. Prev., vol. 45, pp. 204-210, 2012. 
[22] T. Afifi, E. Liwenga, and L. Kwezi, "Rainfall-induced crop failure, food insecurity and out-migration in SameKilimanjaro, Tanzania,” Clim. Dev., vol. 6, no. 1, pp. 53-60, 2014.

[23] R. Miller, C. Acton, D. A. Fullerton, and J. Maltby, "SPSS for Social Scientists," Book, pp. 1-353, 2007.

[24] WHO, "Cholera : transmission , symptoms and treatment Community health promotion Cholera is an acute , diarrhoeal illness caused by the Mode of transmission Cholera : prevention Community health promotion Prevention," Report, pp. 1$2,2011$.

[25] D. Morof et al., "Community mortality from cholera: Urban and rural districts in Zimbabwe," Am. J. Trop. Med. Hyg., vol. 88, no. 4, pp. 645-650, 2013.

[26] E. Burnett et al., "Knowledge, Attitudes, and Practices regarding Diarrhea and Cholera following an Oral Cholera Vaccination Campaign in the Solomon Islands," PLoS Negl. Trop. Dis., vol. 10, no. 8, pp. 1-9, 2016.

[27] K. M. Saif-Ur-Rahman et al., "Promotion of cholera awareness among households of cholera patients: A randomized controlled trial of the cholera-hospital-based-intervention-for-7 days (chobi7) intervention," Am. J. Trop. Med. Hyg., vol. 95, no. 6, pp. 1292-1298, 2016.

[28] V. Were et al., "Evaluation of a Rapid Cholera Response Activity--Nyanza Province, Kenya, 2008,” J. Infect. Dis., vol. 208, no. suppl 1, pp. S62-S68, 2013.

[29] B. Taylor, E. Chinamo, yahoocouk Ben Taylor, and darajaorg Sarah House, "Extended Analysis of Women, Children and the Water, Sanitation and Hygiene Sector in Tanzania," vol. 2009, no. September, 2009.

\section{AUTHORS BIOGRAPHS}

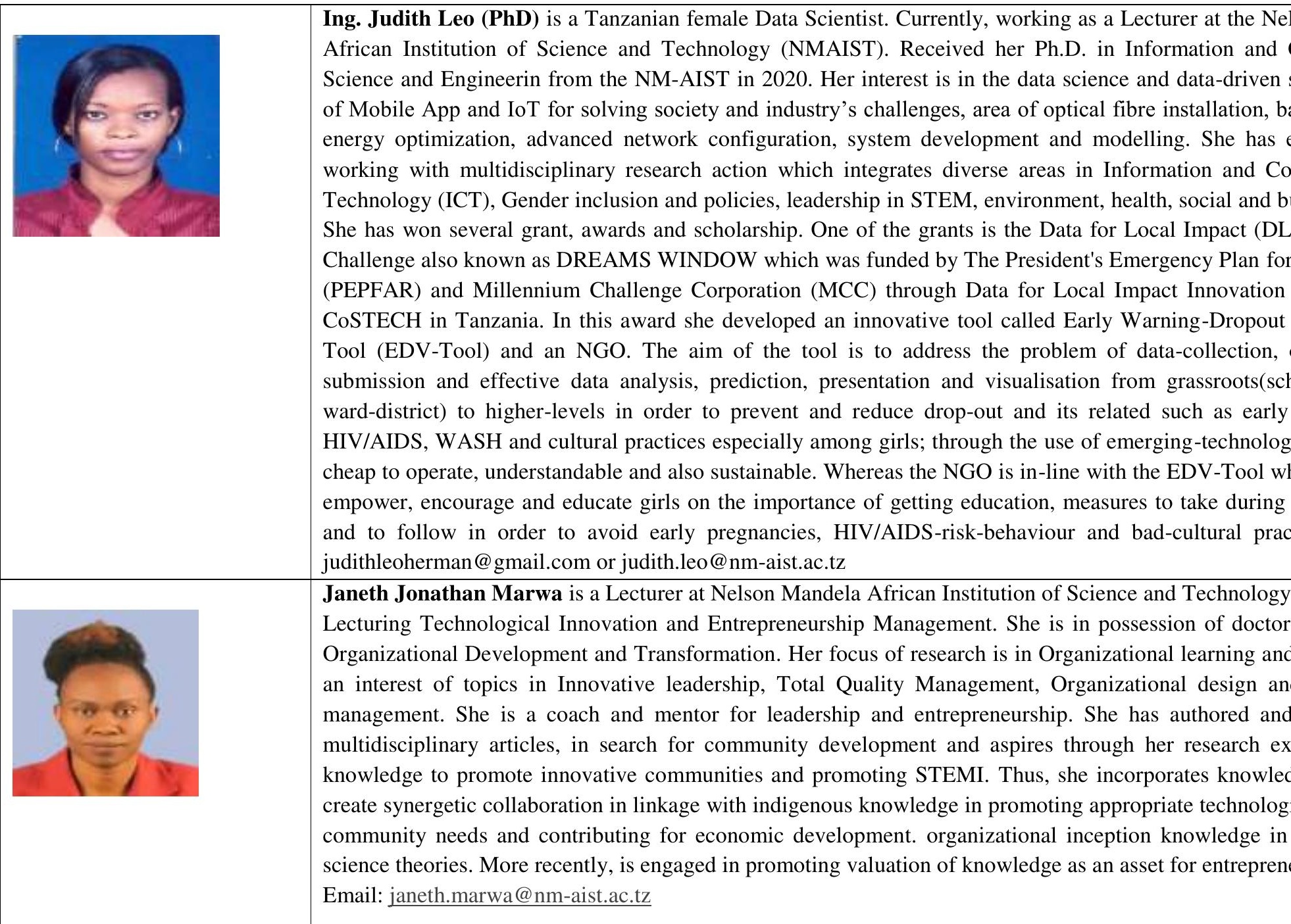

